\title{
Photobacterium ganghwense sp. nov., a halophilic bacterium isolated from sea water
}

\author{
Yoon-Dong Park, ${ }^{1}$ Keun Sik Baik, ${ }^{2}$ Chi Nam Seong, ${ }^{2}$ Kyung Sook Bae, ${ }^{3}$ \\ Sanggoo Kim ${ }^{1}$ and Jongsik Chun ${ }^{1}$
}

Correspondence

Jongsik Chun

jchun@snu.ac.kr

\author{
${ }^{1}$ School of Biological Sciences and Institute of Microbiology, Seoul National University, \\ 56-1 Shillim-dong, Kwanak-gu, Seoul 151-742, Republic of Korea \\ ${ }^{2}$ Department of Biology, College of Natural Sciences, Sunchon National University, Sunchon \\ 540-742, Republic of Korea \\ ${ }^{3}$ Korean Collection for Type Cultures, Korea Research Institute of Bioscience and \\ Biotechnology, Taejon 305-600, Republic of Korea
}

\begin{abstract}
A marine bacterial strain, designated $\mathrm{FR} 1311^{\top}$, was isolated from a sea-water sample from Ganghwa Island, South Korea. Cells were Gram-negative, facultatively anaerobic, catalase- and oxidase-positive, motile, oval or rod-shaped and halophilic (optimum sea-salt concentration for growth of 5-6\%). Phylogenetic analysis of its $16 \mathrm{~S}$ rRNA gene sequence revealed that it represented a distinct line of descent within the genus Photobacterium. The major fatty acids were straight-chain saturated $\left(C_{16: 0}\right)$ and monounsaturated fatty acids $\left(C_{16: 1} \omega 7 c\right.$ and $\left.C_{18: 1} \omega 7 c\right)$. The predominant respiratory lipoquinone was $\mathrm{Q}-8$. The DNA G+C content was $44 \mathrm{~mol} \%$. The phenotypic features of strain FR $1199^{\top}$ were similar to those of Photobacterium damselae subsp. damselae and Photobacterium damselae subsp. piscicida, but several physiological and chemotaxonomic properties readily distinguish the new isolate from them. On the basis of the polyphasic results revealed in this study, $\mathrm{FR} 1311^{\top}$ is considered to be the type strain of a novel species, for which the name Photobacterium ganghwense sp. nov. is proposed. The type strain is FR $1311^{\top}\left(=\right.$ IMSNU $60287^{\top}=$ KCTC $12328^{\top}=$ JCM $\left.12487^{\top}\right)$.
\end{abstract}

The genus Photobacterium was first described by Beijerinck (1889) and at the time of writing the genus comprises 11 recognized species: Photobacterium phosphoreum (Reichelt \& Baumann, 1973) (the type species), P. fischeri (Beijerinck, 1889; Reichelt \& Baumann, 1973), P. leiognathi (Boisvert et al., 1967; Ast \& Dunlap, 2004), P. angustum (Reichelt et al., 1976), P. damselae (Smith et al., 1991), P. iliopiscarium (Onarheim et al., 1994; Urakawa et al., 1999), P. profundum (Nogi et al., 1998), P. indicum (Xie \& Yokota, 2004), P. lipolyticum (Yoon et al., 2005), P. rosenbergii (Thompson et al., 2005) and P. frigidiphilum (Seo et al., 2005). Phylogenetic analyses based on 16S rRNA gene sequences have shown that the genus Photobacterium is closely related to the genus Vibrio (Nogi et al., 1998; Anzai et al., 2000), and has Q-8 as the predominant respiratory lipoquinone and $\mathrm{C}_{16: 1}$ and $\mathrm{C}_{16: 0}$ as the major fatty acids (Nogi et al., 1998). During the course of a study on marine microbial diversity, a halophilic

Published online ahead of print on 18 November 2005 as DOI 10.1099/ijs.0.63811-0.

The GenBank/EMBL/DDBJ accession number for the 16S rRNA gene sequence of strain $\mathrm{FR} 1311^{\top}$ is AY960847.

A transmission electron micrograph of a negatively stained cell of strain $\mathrm{FR} 1311^{\top}$ is available as supplementary material in IJSEM Online. bacterium, designated strain $\mathrm{FR} 1311^{\mathrm{T}}$, was isolated from a sea-water sample and was the subject of a taxonomic investigation. On the basis of the polyphasic evidence presented, this strain is considered to represent a novel species of the genus Photobacterium.

A sample was collected in coastal surface sea water from Ganghwa Island, South Korea $\left(37^{\circ} 35^{\prime} 39 \cdot 1^{\prime \prime} \mathrm{N} 126^{\circ} 27^{\prime}\right.$ $\left.24 \cdot 5^{\prime \prime} \mathrm{E}\right)$. The sample was diluted with sterilized artificial sea water (ASW; Lyman \& Fleming, 1940), spread onto a plate containing marine agar 2216 (MA) (Becton Dickinson) and incubated at $25^{\circ} \mathrm{C}$ for 3 weeks. The isolate was routinely cultured on MA and maintained as a glycerol suspension $(20 \%, w / v)$ at $-80{ }^{\circ} \mathrm{C}$.

The 16S rRNA gene sequence of this strain, designated FR $1311^{\mathrm{T}}$, was determined using universal primers (Lane, 1991) as described by Chun \& Goodfellow (1995), and an almost complete sequence was obtained (1462 bp). Phylogenetic analyses were performed using the Fitch-Margoliash (Fitch \&Margoliash, 1967), maximum-likelihood (Felsenstein, 1993), maximum-parsimony (Fitch, 1971) and neighbourjoining (Saitou \& Nei, 1987) methods. Evolutionary distance matrices were generated according to Jukes \& Cantor (1969). The topology of the resultant neighbour-joining tree 
was evaluated by bootstrap analyses (Felsenstein, 1985) based on 1000 resamplings. Alignment and phylogenetic analyses were carried out using the jPHYDIT program (available at http://chunlab.snu.ac.kr/jphydit/) and PAUP 4.0 (Swofford, 1998) as described by Chun et al. (2000).

Preliminary sequence comparison with $16 \mathrm{~S}$ rRNA gene sequences held in GenBank indicated that the new isolate belongs within the genus Photobacterium. The newly determined sequence was then aligned manually against representatives of the family Vibrionaceae using bacterial $16 \mathrm{~S}$ rRNA gene secondary structure information. Domains used to construct the phylogenetic trees were the regions available for all sequences (positions 85-1417; Escherichia coli numbering system). On the basis of $16 \mathrm{~S}$ rRNA gene sequence similarity, the closest cultured bacterial relatives were the type strains of recognized Photobacterium species $(95 \cdot 5-92 \cdot 7 \%)$ and Vibrio species $(92 \cdot 7-91 \cdot 1 \%)$. Strain FR $1131^{\mathrm{T}}$ showed highest $16 \mathrm{~S}$ rRNA gene sequence similarity to $P$. damselae subsp. damselae ATCC $33539^{\mathrm{T}}(95 \cdot 5 \%)$, followed by $P$. damselae subsp. piscicida NCIMB $2058^{\mathrm{T}}$ $(95 \cdot 4 \%)$, P. rosenbergii LMG $22223^{\mathrm{T}}(94 \cdot 9 \%)$ and P. leiognathi ATCC $25521^{\mathrm{T}}(94 \cdot 4 \%)$. These values are well below the cut-off value of $97 \%$ suggested for bacterial species definition (Stackebrandt \& Goebel, 1994). As shown in the neighbour-joining phylogenetic tree (Fig. 1), strain FR $1311^{\mathrm{T}}$ formed a distinct phyletic subline within the genus Photobacterium; this relationship was confirmed using the other tree-making algorithms. On the basis of pairwise $16 \mathrm{~S}$ rRNA gene sequence similarity and phylogenetic analysis, it is clear that the new isolate represents a novel species in the genus Photobacterium.

For phenotypic tests, strain $\mathrm{FR} 1311^{\mathrm{T}}$ was grown on MA at $30^{\circ} \mathrm{C}$. Cellular morphologies were observed by use of a differential interference microscope (Axioskop 40; Zeiss) and a transmission electron microscope (JEM1010; JEOL) using cells grown at $25^{\circ} \mathrm{C}$ for 3 days. Motility was examined using wet mounts. The $\mathrm{pH}$ range $(\mathrm{pH} 3-12)$ for growth was determined using MA. The requirement of $\mathrm{NaCl}(0-10 \%)$ for growth was tested using synthetic ZoBell medium (ZoBell, 1941; $15 \mathrm{~g}$ Bacto agar, $5 \mathrm{~g}$ Bacto peptone, $1 \mathrm{~g}$ yeast extract, $0 \cdot 1 \mathrm{~g}$ ferric citrate in $1000 \mathrm{ml}$ distilled water). Growth at various temperatures was examined on MA at $4-50{ }^{\circ} \mathrm{C}$. Accumulation of poly- $\beta$-hydroxybutyrate was determined by the Sudan black staining method (Smibert \& Krieg, 1994). Biochemical tests were performed using the API 20NE, API 20E and API ZYM kits (bioMérieux). Strips were inoculated with a heavy bacterial suspension in ASW or AUX medium (bioMérieux) supplemented with $2 \%$ sea salts. Catalase and oxidase activities were determined using $3 \%(\mathrm{v} / \mathrm{v})$ hydrogen peroxide and Kovacs reagent (Kovacs, 1956), respectively. Cell biomass of strain FR $1311^{\mathrm{T}}$ for respiratory lipoquinone analysis and for DNA extraction was obtained from cultivation in marine broth 2216 (Becton Dickinson) at $25^{\circ} \mathrm{C}$. Isoprenoid quinones were extracted and analysed as described by Komagata \& Suzuki (1987) using reversed-phase TLC. Cellular fatty acids were analysed as methyl esters by GLC according to the instructions of the Microbial Identification System (MIDI). Fatty acid methyl esters were prepared from biomass grown on $\mathrm{MA}$ at $30^{\circ} \mathrm{C}$ for 2 days. DNA G $+\mathrm{C}$ content was determined according to the thermal denaturation method described by Marmur \& Doty (1962).

Strain FR $1311^{\mathrm{T}}$ was halophilic; it required $1-7 \%(\mathrm{w} / \mathrm{v}) \mathrm{NaCl}$ for growth (optimum 2\%) and was unable to grow on ZoBell medium without $\mathrm{NaCl}$. Results of the biochemical and physiological tests are given in the species description

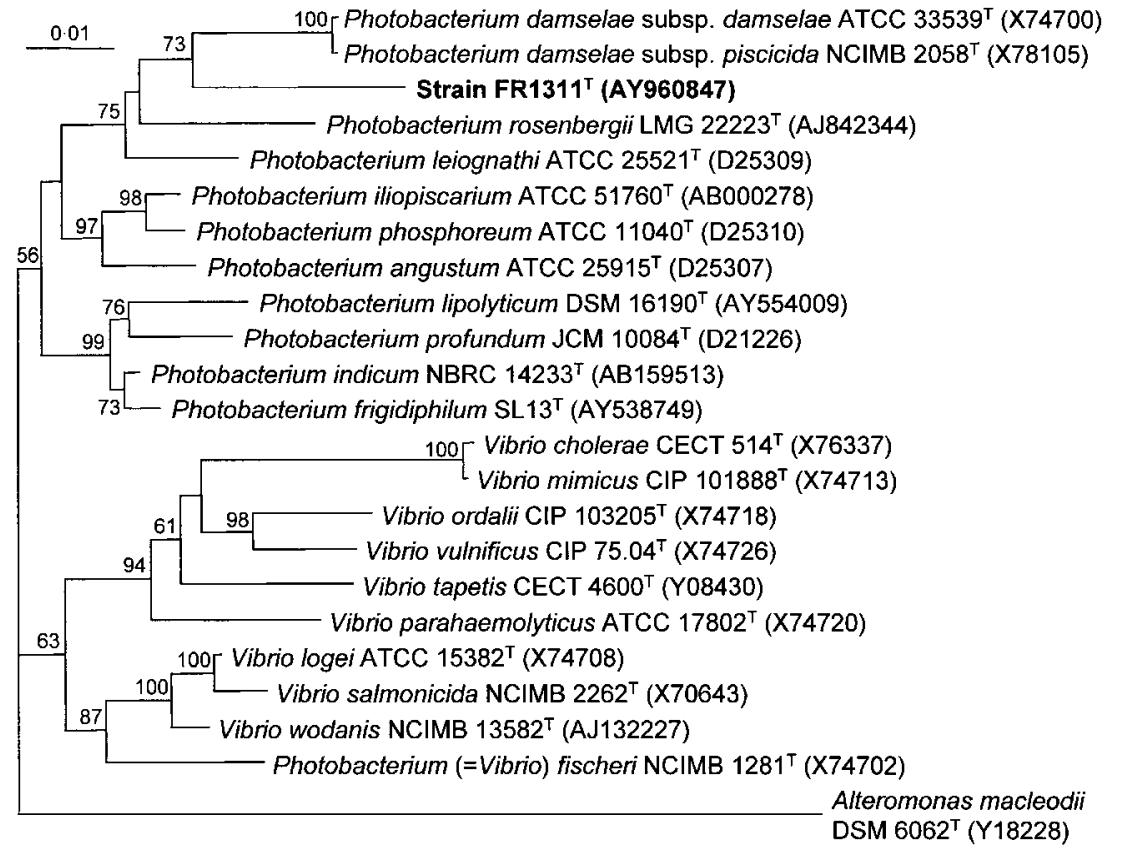

Fig. 1. Neighbour-joining tree based on nearly complete $16 \mathrm{~S}$ rRNA gene sequences showing relationships between strain FR $1131^{\top}$ and members of the genus Photobacterium. Numbers at nodes indicate levels of bootstrap support (\%) for branch points based on 1000 resamplings. Alteromonas macleodii DSM $6062^{\top}$ was used as an outgroup. Bar, 0.01 nucleotide substitutions per position. 
and in Table 1. Strain FR $1311^{\mathrm{T}}$ had an unsaturated ubiquinone with eight isoprene units $(\mathrm{Q}-8)$, in agreement with previous findings that photobacteria contain Q-8 as the predominant respiratory lipoquinone (Nogi et al., 1998). Strain FR $1311^{\mathrm{T}}$ had large amounts of straight-chain and unsaturated fatty acids: the major components were $\mathrm{C}_{16: 0}$ $(21 \%), \mathrm{C}_{14: 0}(3 \cdot 6 \%), \mathrm{C}_{12: 0}(3 \cdot 4 \%), \mathrm{C}_{18: 1} \omega 7 c(29 \cdot 6 \%)$, $\mathrm{C}_{12: 0} 3-\mathrm{OH}(2 \cdot 1 \%), \mathrm{C}_{16: 1} \omega 7 c$ and/or iso- $\mathrm{C}_{15: 0} 2-\mathrm{OH}$ $(27 \cdot 8 \%)$ and $\mathrm{C}_{14: 0} 3-\mathrm{OH}$ and/or iso- $\mathrm{C}_{16: 1}(2 \cdot 7 \%)$. This fatty acid profile is similar to those of recognized Photobacterium species (Nogi et al., 1998).

The detailed results of biochemical, substrate utilization and DNA G $+\mathrm{C}$ content determinations are given in Table 1 and the species description. It is evident from Table 1 that there are several phenotypic characters that readily separate strain FR $1311^{\mathrm{T}}$ from phylogenetically related species. Together with 16S rRNA gene and chemotaxonomic analyses, it is evident that strain FR $1311^{\mathrm{T}}$ should be classified as a novel species in the genus Photobacterium, for which the name Photobacterium ganghwense sp. nov. is proposed.

\section{Description of Photobacterium ganghwense sp. nov.}

Photobacterium ganghwense (gang.hwen'se. N.L. neut. adj. ganghwense pertaining to Ganghwa Island, Korea, the geographical origin of the type strain of the species).

Gram-negative, oxidase- and catalase-positive and facultatively anaerobic. Colonies on MA are circular, smooth, convex with entire margins, slightly cream-coloured and approximately $3 \mathrm{~mm}$ in diameter after 3 days at $30^{\circ} \mathrm{C}$. Cells are motile by means of a polar flagellum (see Supplementary Fig. S1 in IJSEM Online), are oval or rod-shaped and $0 \cdot 8$ $1 \cdot 2 \times 1 \cdot 3-2 \cdot 0 \mu \mathrm{m}$ in size. Spores are not formed. Growth occurs in $1-7 \%(\mathrm{w} / \mathrm{v}) \mathrm{NaCl}$ (optimum $2 \%$ ). Growth occurs at pH 5-11 (optimum pH 8-9) and at $10-45^{\circ} \mathrm{C}$ (optimum

Table 1. Differential physiological and biochemical characteristics between strain FR $1311^{\top}$ and other Photobacterium species

Strains: 1, strain FR1311 ${ }^{\mathrm{T}}$; 2, P. damselae subsp. damselae ATCC $33539^{\mathrm{T}}$ (data from Smith et al., 1991; Nogi et al., 1998); 3, P. damselae subsp. piscicida NCIMB 2058 ${ }^{\mathrm{T}}$ (Gauthier et al., 1995); 4, P. rosenbergii LMG 22223 ${ }^{\mathrm{T}}$ (Thompson et al., 2005); 5, P. leiognathi ATCC 25521 ${ }^{\mathrm{T}}$ (Baumann \& Baumann, 1984; Nogi et al., 1998); 6, P. angustum ATCC 25915 (Baumann \& Baumann, 1984; Nogi et al., 1998); 7, P. iliopiscarium ATCC $51760^{\mathrm{T}}$ (Onarheim et al., 1994); 8, P. phosphoreum ATCC $11040^{\mathrm{T}}$ (Reichelt \& Baumann, 1973; Baumann \& Baumann, 1984; Nogi et al., 1998); 9, P. frigidiphilum SL13 ${ }^{\mathrm{T}}$ (Seo et al., 2005); 10, P. indicum NBRC $14233^{\mathrm{T}}$ (Xie \& Yokota, 2004); 11, P. profundum JCM $10084^{\mathrm{T}}$ (Nogi et al., 1998); 12, P. lipolyticum DSM 16190 ${ }^{\mathrm{T}}$ (Yoon et al., 2005). +, Positive reaction or production; - , negative reaction or no production; $\mathrm{W}$, weakly positive; $\mathrm{V}$, variable; ND, data not available.

\begin{tabular}{|c|c|c|c|c|c|c|c|c|c|c|c|c|}
\hline Characteristic & 1 & 2 & 3 & 4 & 5 & 6 & 7 & 8 & 9 & 10 & 11 & 12 \\
\hline Catalase & + & + & + & ND & - & - & + & + & + & - & + & + \\
\hline Optimum growth temperature $\left({ }^{\circ} \mathrm{C}\right)$ & 35 & $22-26$ & $25-35$ & $20-30$ & 26 & 25 & 20 & 18 & 14 & 25 & 10 & $25-28$ \\
\hline \multicolumn{13}{|l|}{ Growth at: } \\
\hline $4^{\circ} \mathrm{C}$ & - & - & - & - & - & $\mathrm{V}$ & + & + & - & + & + & + \\
\hline Lysine decarboxylase & - & - & - & - & - & - & + & - & ND & - & - & - \\
\hline Citrate utilization & + & - & - & + & - & - & - & - & - & - & - & - \\
\hline Production of $\mathrm{H}_{2} \mathrm{~S}$ & - & - & - & ND & - & - & - & - & ND & + & - & - \\
\hline Indole production & + & - & - & - & - & - & - & - & + & + & + & + \\
\hline Acetoin production & - & + & + & - & + & + & + & + & ND & ND & + & - \\
\hline \multicolumn{13}{|l|}{ Fermentation of: } \\
\hline D-Mannitol & + & - & - & + & - & - & - & - & + & $\mathrm{ND}$ & + & - \\
\hline D-Sorbitol & - & - & + & - & - & - & - & - & ND & ND & - & - \\
\hline L-Rhamnose & $\mathrm{W}$ & - & - & + & - & - & - & - & ND & ND & - & - \\
\hline Sucrose & - & - & $\mathrm{W}$ & + & - & + & - & - & + & + & - & + \\
\hline Melibiose & - & + & - & + & - & - & - & - & ND & ND & - & - \\
\hline L-Arabinose & - & - & + & - & - & - & - & - & ND & - & - & - \\
\hline Assimilation of maltose & + & - & - & + & + & + & + & + & + & + & + & + \\
\hline DNA G $+C$ content $(\mathrm{mol} \%)$ & 44 & 41 & 41 & 48 & 40 & 40 & $38-40$ & $39-42$ & 44 & 40 & 42 & 47 \\
\hline
\end{tabular}


$35^{\circ} \mathrm{C}$ ). Bioluminescence is observed. No gas is produced from D-glucose under aerobic conditions. Growth occurs on thiosulfate/citrate/bile salts/sucrose medium (TCBS agar; Oxoid), producing green colonies. Acid is formed from glucose. Does not produce ornithine decarboxylase, urease or tryptophan deaminase. Does not hydrolyse aesculin. Positive for fermentation of glucose, D-inositol and amygdalin. Positive for assimilation of glucose, mannitol, $\mathrm{N}$-acetylD-glucosamine, gluconate, malate, citrate and phenylacetate. Mannose, caprate and adipate are weakly utilized. Produces alkaline phosphatase, esterase (C4), esterase lipase (C8), leucine arylamidase, acid phosphatase, naphthol-ASBI-phosphohydrolase and $\alpha$-glucosidase, but not lipase (C14), valine arylamidase, cystine arylamidase, trypsin, $\alpha$-chymotrypsin, $\alpha$-galactosidase, $\beta$-galactosidase, $\beta$-glucuronidase, $\beta$-glucosidase, $N$-acetyl- $\beta$-glucosaminidase, $\alpha$ mannosidase or $\beta$-fucosidase. Other physiological and biochemical characteristics are given in Table 1. Major fatty acids are $\mathrm{C}_{18: 1} \omega 7 c(29 \cdot 6 \%), \mathrm{C}_{16: 1} \omega 7 c$ and/or iso- $\mathrm{C}_{15: 0}$ 2-OH $(27 \cdot 8 \%)$ and $\mathrm{C}_{16: 0}(21 \cdot 1 \%)$. The DNA G $+\mathrm{C}$ content is $44 \mathrm{~mol} \%$.

The type strain, FR $1311^{\mathrm{T}}\left(=\mathrm{IMSNU} \quad 60287^{\mathrm{T}}=\mathrm{KCTC}\right.$ $12328^{\mathrm{T}}=$ JCM $12487^{\mathrm{T}}$ ), was isolated from sea water from Ganghwa Island, South Korea.

\section{Acknowledgements}

This work was supported, in part, by the Korea Ministry of Science and Technology under National Research Laboratory Program (M10500000110-05J0000-11010) and 21C Frontier Microbial Genomics and Applications Center Program (MG05-0101-2-0).

\section{References}

Anzai, Y., Kim, H., Park, J.-Y., Wakabayashi, H. \& Oyaizu, H. (2000). Phylogenetic affiliation of the pseudomonads based on 16S rRNA sequence. Int J Syst Evol Microbiol 50, 1563-1589.

Ast, J. C. \& Dunlap, P. V. (2004). Phylogenetic analysis of the lux operon distinguishes two evolutionarily distinct clades of Photobacterium leiognathi. Arch Microbiol 181, 352-361.

Baumann, P. \& Baumann, L. (1984). Genus II. Photobacterium Beijerinck 1889, $401^{\mathrm{AL}}$. In Bergey's Manual of Systematic Bacteriology, vol. 1, pp. 539-545. Edited by N. R. Krieg \& J. G. Holt. Baltimore: Williams \& Wilkins.

Beijerinck, M. W. (1889). Le Photobacterium luminosum. Bactérie luminosum de la Mer Nord. Arch Néerl Sci 23, 401-427 (in French).

Boisvert, H., Chatelain, R. \& Bassot, J.-M. (1967). Etude d'un Photobacterium isolé de l'organe lumineux de poissons Leiognathidae. Ann Inst Pasteur 112, 520-524 (in French).

Chun, J. \& Goodfellow, M. (1995). A phylogenetic analysis of the genus Nocardia with $16 \mathrm{~S}$ rRNA gene sequences. Int J Syst Bacteriol 45, 240-245.

Chun, J., Bae, K. S., Moon, E. Y., Jung, S. O., Lee, H. K. \& Kim, S. J. (2000). Nocardiopsis kunsanensis sp. nov., a moderately halophilic actinomycete isolated from a saltern. Int J Syst Evol Microbiol 50, 1909-1913.

Felsenstein, J. (1985). Confidence limits on phylogenies: an approach using the bootstrap. Evolution 39, 783-791.
Felsenstein, J. (1993). PHYLIP - phylogenetic inference package, version 3.5c. Distributed by the author. Department of Genome Sciences, University of Washington, Seattle, USA.

Fitch, W. M. (1971). Toward defining the course of evolution: minimum change for a specific tree topology. Syst Zool 20, 406-416.

Fitch, W. M. \& Margoliash, E. (1967). Construction of phylogenetic trees: a method based on mutation distances as estimated from cytochrome $c$ sequences is of general applicability. Science 155, 279-284.

Gauthier, G., Lafay, B., Ruimy, R., Breittmayer, V., Nicolas, J. L., Gauthier, M. \& Christen, R. (1995). Small-subunit rRNA sequences and whole DNA relatedness concur for the reassignment of Pasteurella piscicida (Snieszko et al.) Janssen and Surgalla to the genus Photobacterium as Photobacterium damsela subsp. piscicida comb. nov. Int J Syst Bacteriol 45, 139-144.

Jukes, T. H. \& Cantor, C. R. (1969). Evolution of protein molecules. In Mammalian Protein Metabolism, vol. 3, pp. 21-132. Edited by H. N. Munro. New York: Academic Press.

Komagata, K. \& Suzuki, K. (1987). Lipids and cell-wall analysis in bacterial systematics. Methods Microbiol 19, 161-203.

Kovacs, N. (1956). Identification of Pseudomonas pyocyanea by the oxidase reaction. Nature 178, 703.

Lane, D. J. (1991). 16S/23S rRNA sequencing. In Nucleic Acid Techniques in Bacterial Systematics, pp. 115-175. Edited by M. Goodfellow. Chichester: Wiley.

Lyman, J. \& Fleming, R. H. (1940). Composition of sea water. J Mar Res 3, 134-146.

Marmur, J. \& Doty, P. (1962). Determination of the base composition of deoxyribonucleic acid from its thermal denaturation temperature. J Mol Biol 5, 109-118.

Nogi, Y., Masui, N. \& Kato, C. (1998). Photobacterium profundum sp. nov., a new, moderately barophilic bacterial species isolated from a deep-sea sediment. Extremophiles 2, 1-7.

Onarheim, A. M., Wiik, R., Burghardt, J. \& Stackebrandt, E. (1994). Characterization and identification of two Vibrio species indigenous to the intestine of fish in cold sea water; description of Vibrio iliopiscarius sp. nov. Syst Appl Microbiol 17, 370-379.

Reichelt, J. L. \& Baumann, P. (1973). Taxonomy of the marine, luminous bacteria. Arch Microbiol 94, 283-330.

Reichelt, J. L., Baumann, P. \& Baumann, L. (1976). Study of genetic relationships among marine species of the genera Beneckea and Photobacterium. Arch Microbiol 110, 101-120.

Saitou, N. \& Nei, M. (1987). The neighbor-joining method: a new method for reconstructing phylogenetic trees. Mol Biol Evol 4, 406-425.

Seo, H. J., Bae, S. S., Lee, J. H. \& Kim, S. J. (2005). Photobacterium frigidiphilum sp. nov., a psychrophilic, lipolytic bacterium isolated from deep-sea sediments of Edison Seamount. Int $J$ Syst Evol Microbiol 55, 1661-1666.

Smibert, R. M. \& Krieg, N. R. (1994). Phenotypic characterization. In Methods for General and Molecular Microbiology, pp. 611-654. Edited by P. Gerhardt, R. G. E. Murray, W. A. Wood \& N. R. Krieg. Washington, DC: American Society for Microbiology.

Smith, S. K., Sutton, D. C., Fuerst, J. A. \& Reichelt, J. L. (1991). Evaluation of the genus Listonella and reassignment of Listonella damsela (Love et al.) MacDonell and Colwell to the genus Photobacterium as Photobacterium damsela comb. nov. with an emended description. Int J Syst Bacteriol 41, 529-534.

Stackebrandt, E. \& Goebel, B. M. (1994). Taxonomic note: a place for DNA-DNA reassociation and $16 \mathrm{~S}$ rRNA sequence analysis in the present species definition in bacteriology. Int J Syst Bacteriol 44, 846-849.

Swofford, D. L. (1998). PAUP - phylogenetic analysis using parsimony, version 4. Sunderland, MA: Sinauer Associates. 
Thompson, F. L., Thompson, C. C., Naser, S., Hoste, B., Vandemeulebroecke, K., Munn, C., Bourne, D. \& Swings, J. (2005). Photobacterium rosenbergii sp. nov. and Enterovibrio coralii sp. nov., vibrios associated with coral bleaching. Int J Syst Evol Microbiol 55, 913-917.

Urakawa, H., Kita-Tsukamoto, K. \& Ohwada, K. (1999). Reassessment of the taxonomic position of Vibrio iliopiscarius (Onarheim et al. 1994) and proposal for Photobacterium iliopiscarium comb. nov. Int J Syst Bacteriol 49, 257-260.
Xie, C.-H. \& Yokota, A. (2004). Transfer of Hyphomicrobium indicum to the genus Photobacterium as Photobacterium indicum comb. nov. Int J Syst Evol Microbiol 54, 2113-2116.

Yoon, J.-H., Lee, J.-K., Kim, Y.-O. \& Oh, T.-K. (2005). Photobacterium lipolyticum sp. nov., a bacterium with lipolytic activity isolated from the Yellow Sea in Korea. Int J Syst Evol Microbiol 55, 335-339.

ZoBell, C. E. (1941). Studies on marine bacteria. I. The cultural requirements of heterotrophic aerobes. J Mar Res 4, 42-75. 